УДК 903.01/.09

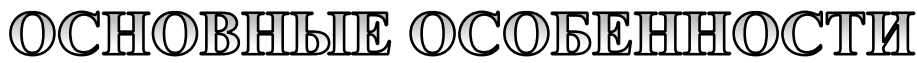

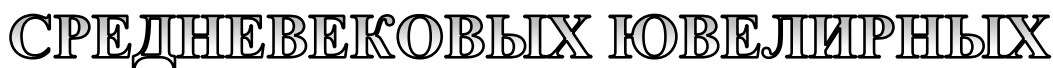

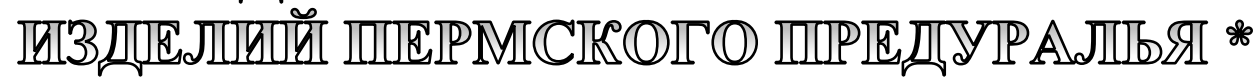

Ю.А. Подосёнова, Пермский федеральный исследовательский центр УрО РАН

\section{Для цитирования:}

Подосёнова Ю.А. Основные особенности средневековых ювелирных изделий Пермского Предуралья // Вестник Пермского федерального исследовательского центра. - 2021. - № 2. - С. 84-93. https://doi.org/10.7242/2658-705X/2021.2.8

В последние годы благодаря результатам исследований ювелирных изделий, обнаруженных на средневековых памятниках Пермского Предуралья, а также новым материалам полевых археологических изысканий последних лет получены убедительные доказательства существования здесь собственных ювелирных центров. Изделия, изготовленные прикамскими мастерами, обеспечивали потребности местного населения и представлены украшениями костюма, а также предметами бытового и ритуального предназначения. Все они обладают рядом отличительных особенностей, выделяющих их среди всего ювелирного наследия территории Евразии в период IX-XIII вв.

Предлагаемая вниманию работа посвящена четкому определению этих отличительных особенностей, которые проявляются не только в материале и форме изделий, но и в способах, приемах их изготовления и декорирования. Прежде всего, это определенные культурнохронологические традиции выполнения отдельных конструктивных элементов, расположение зернофилигранного декора в изготовлении изделий и его техническое исполнение, определенные способы инкрустирования отдельных категорий ювелирных изделий, нанесения позолоты и т.д. Фиксация данных особенностей позволяет более точно атрибутировать изделия, обнаруженные как в средневековых памятниках рассматриваемой территории, так и далеко за ее пределами.

Ключевые слова: Пермское Предуралье, эпоха средневековья, ювелирное ремесло, специфика, изготовление, техника, зернь, филигрань инкрустация, амальгамирование.

Еще до недавнего времени большинство ювелирных украшений из драгоценных металлов, обнаруженных на средневековых памятниках Пермского Предуралья, было принято считать исключительно импортными изделиями, которые чаще всего определялись как продукция булгарских ювелирных мастерских (в частности, изделия из памятников, датируемых IX-XIII вв.) $[1$, с. $142-148 ; \quad 2$, с. $28-29 ; \quad 5$, с. 12 ; 13, с. 89-97]. Однако результаты комплексного исследования разных категорий

\footnotetext{
* Работа выполнена при финансовой поддержке гранта РФФИ и Пермского края, проект №20-49-590001 «Средневековое ювелирное наследие Пермского края: стилистические и химико-технологические особенности».
} 
ювелирных изделий с территории Пермского Предуралья [3, с. 49-60; 4, с. 86-93; 7, с. $38-44 ; 8$, с. $100-105 ; 9$, с. $187-191 ; 6]$, сравнение их с собственно булгарскими украшениями с территории Волжской Булгарии $[11$, с. $288-289 ; 12$, с. $97,101-$ 102], новые археологические источники, полученные при полевых изысканиях последних лет (весомое пополнение коллекции средневековых ювелирных изделий, открытие ювелирных мастерских на поселенческих памятниках, находки комплексов ювелирных инструментов на могильниках), позволили исследователям прийти к выводу о местном происхождении большинства украшений из драгоценных металлов и их изготовлении в собственных ювелирных мастерских.

Время возникновения, развития и функционирования ювелирного ремесла на рассматриваемой территории укладывается в период с IX до конца XIII вв. Результаты исследований показывают, что прикамское ювелирное ремесло не являлось замкнутым и воспринимало многие технические инновации по мере их возникновения [10, с. 162]. Но, в то же время, ему были присущи и черты определенной консервативности - из всего многообразия форм и категорий изделий, соответствовавших средневековой ювелирной моде, воспринимались только те, которые подходили под определенные местные каноны, да и сам ассортимент ювелирных изделий и их типы отличались большой устойчивостью на протяжении длительного периода. Прикамские изделия обладают местной спецификой и рядом отличительных особенностей, которые выделяют их среди прочих похожих синхронных украшений других территорий.

Коллекция украшений весьма объемна, и к настоящему времени насчитывает около 1000 экземпляров (В настоящий момент детально исследовано более половины изделий). Состав представленных категорий вещей отличается большим разнообразием. Подавляющее большинство ювелирных изделий составляют украшения и детали костюма, которые образуют довольно стандартный набор это височные подвески, шейно-нагрудные украшения, украшения кос (накосники), украшения рук (браслеты и перстни), отдельные элементы поясных наборов. В меньшем количестве представлены бытовые предметы, одновременно служившие декоративным элементом костюма (ножны, игольники) и ритуальные предметы (погребальные маски).

Большинство прикамских ювелирных изделий являются сборнылми, состоящими из разных конструктивных элементов, спаянных между собой. Практически все они выполнялись из тонкого прокованного листа металла. Полые конструктивные элементы украшений производились с помощью тиснения, а необъемные, плоские конструктивные элементы с помощью вырезания из тонкого листа металла (рис. 1). Для изготовления проволочных элементов ювелирных

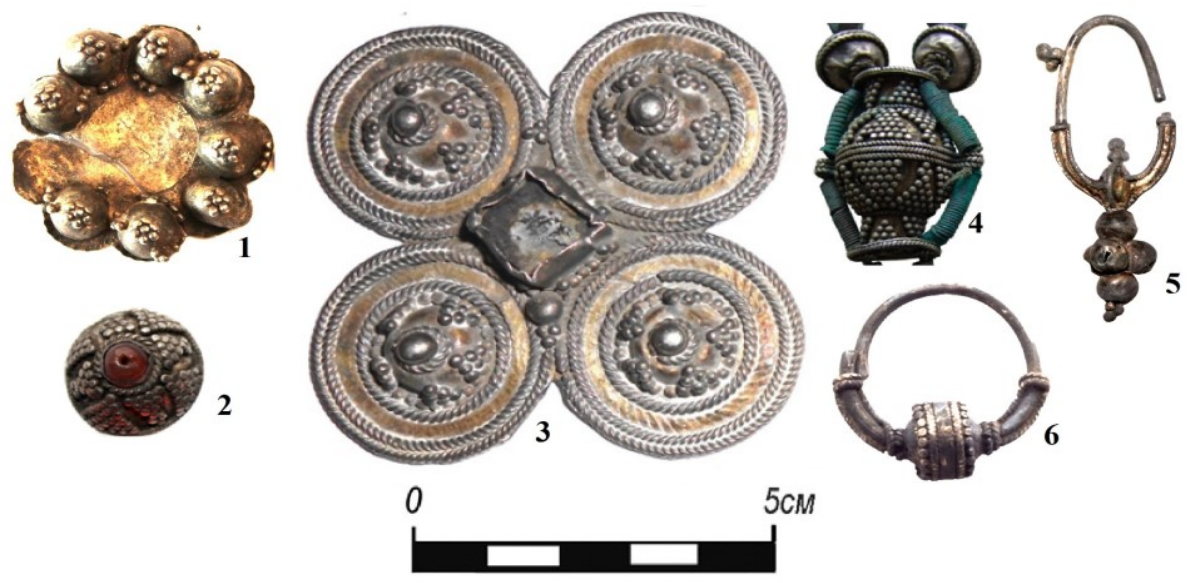

Рис. 1. Ювелирные изделия Пермского Предуралья 
изделий использовалось волочение. Подавляющее большинство прикамских ювелирных изделий выполнено из сереб$p a$. Судя по результатам исследования химического состава металла, преобладающим был сплав с высоким содержанием серебра (Ag более 90\%), что может свидетельствовать о том, что основным сырьем для их производства являлось монетное серебро (преимущественно арабские и булгарские дирхемы). Предметы из золота сравнительно редки и обычно представляют собой изделия простых форм, в изготовлении которых применялись нетрудоемкие технологические приемы (рис. 2).

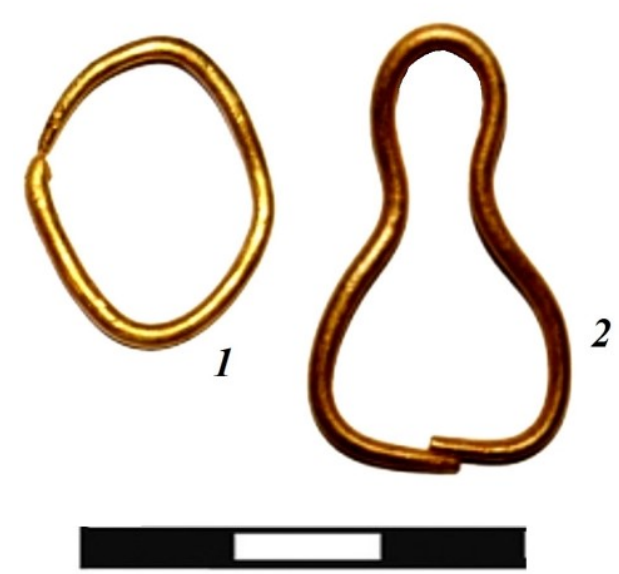

Рис. 2. Золотые прикамские ювелирные изделия простых форм
Прикамские ювелирные изделия

$\boldsymbol{I X - n е р в о и ̆ ~ п о л о в и н ы ~} \boldsymbol{X}$ вв. массово представлены зернофилигранными височными украшениями с грушевидной или гроздьевидной привеской, круглыми пластинчатыми медальонами, звездчатыми медальонами, собранными на медной основе, перстяными украшениями в виде «колпачков», ножнами в серебряных обкладках с зернофилигранным декором или оттиснутыми изображениями, лицевыми пластинами поясных сумочек, погребальными лицевыми покрытиями (масками), изредка - декоративными деталями парадного оружия.

В IX - первой половине X вв. в декорировании изделий массово применялись следующие ювелирные техники: зернь и филигрань, золочение с помощью амальгамирования, инкрустация цветными камнями и стеклом, декорирование изделий с помощью простого орнамента, нанесенного чеканкой. Реже в декорировании изделий фиксируется орнамент, нанесенный с помощью гравировки (дрожжировка), и художественное тиснение.

Зернью выкладывался орнамент из небольших треугольников (реже - ромбов) на пластинчатой основе плоских и объемных полых поверхностей ювелирных изделий (рис. 1/1-3, 7-11), а также создавались объемные пирамидки, применявшиеся в декорировании височных укра-

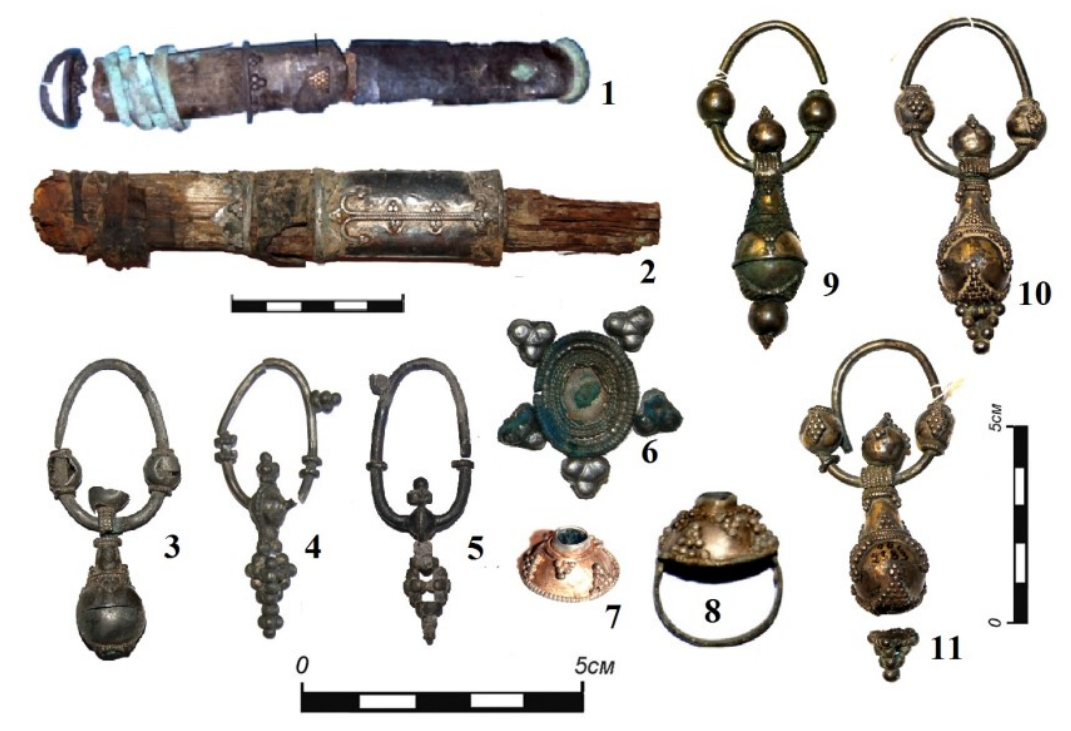

Рис. 3. Ювелирные изделия IX-первой половинь X 
шений (рис. 3/4,5, 9-11), в некоторых изделиях из зерни составлялись отдельные конструктивные элементы (рис. 3/4,5).

Филигранный (проволочный) декор представлен рядами, выложенными из рубчатой штампованной проволочки (рис. 3/2-11), очень редко - из гладкой проволоки (рис. 3/9). Филигранные ряды в основном выкладывались на местах стыка отдельных конструктивных элементов (прикрывали их). Гораздо реже филигрань, уложенная в один-два ряда, выступала исключительно как декоративный элемент (рис. 3/2,4-6,9).

Шталпованная проволочка периода $\mathrm{IX}$ - первой половины X вв. имеет зерневой эффект. «Зерна» на штампованной проволочке выделяются отчетливо, они аккуратные, имеют равный шаг и фикси- руются со всех сторон. Но в то же время в них прослеживаются различия - в одних изделиях зерна на штампованной проволочке имеют правильную шаровидную форму, в других - они также правильной формы, но с небольшим разрезом в средней части. Возможно, эти отличия свидетельствуют о применении разных видов специализированного инструмента для изготовления филиграни (рис. 4).

Фон изделий, свободный от зернофилигранного декора, декорировался позолотой $c$ помощью амальгамирования (рис. 3/7-11). Отдельные изделия декорированы вставками (округлой, овальной, каплевидной формы) из разных материалов: янтаря, поделочных и полудрагоценных камней (преимущественно сердолика) (рис. 5). В качестве вставок иногда
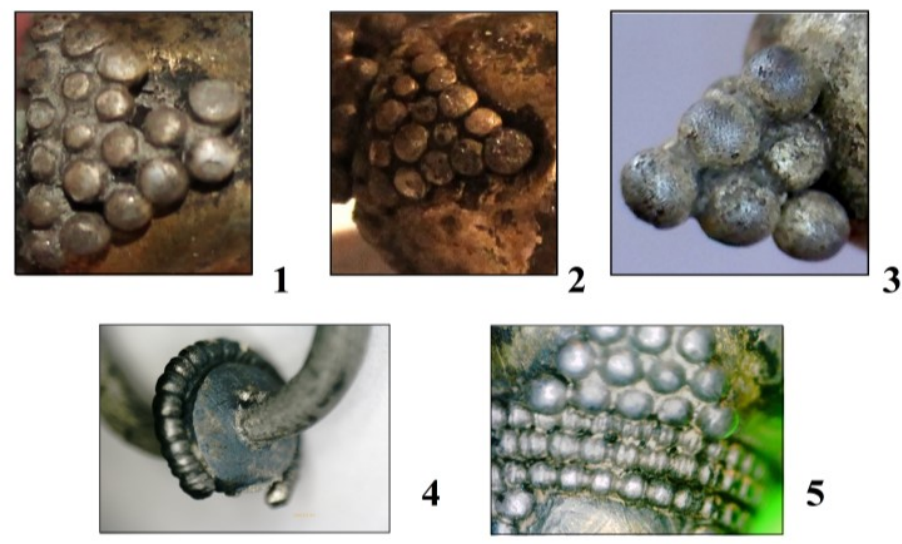

5
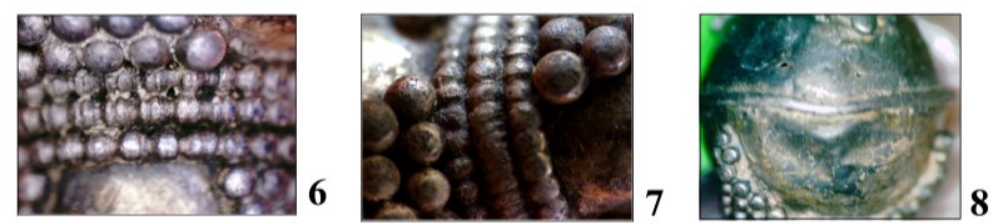

Рис. 4. Зернофилигранный декор в ювелирных изделиях Пермского Предуралья
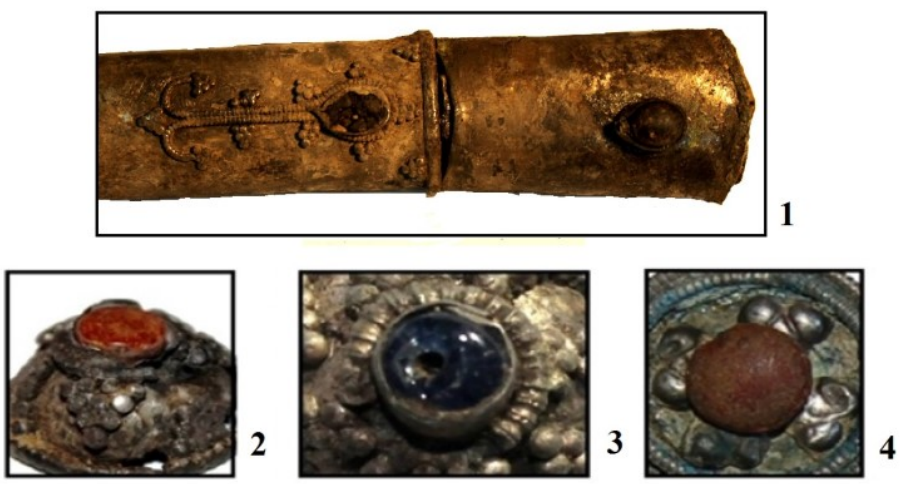

Рис. 5. Инкрустация в прикамских ювелирных изделиях IX-первой половины X вв. 
употреблялись также целые и расколотые бусины разных форм из камня и стекла (рис. 5/3), янтаря (рис. 5/1,2,4), смолы (рис. 5/1). Вставка помещалась в специально подготовленный глухой $к a c m$, изготовленный из полоски металла, согнутой по форме вставки и припаянной на металлическую основу изделия. Вставки в касте закреплены небольшим заваливанием его краев. Дополнительно вставка подклеена на основу изделия веществом, напоминающим смолу.
Изделия простых форм (пластинчатые медальоны, элементы ножен, лицевых пластин поясных кошельков, маски) по краю декорированы с помощью чеканки округльмм выпуклинами, нанесенными в ряд по контуру, реже - образующими орнамент из треугольников, имитирующий зерневой декор (рис. 6/1-3).

Изредка в этот период в декорировании изделий применялись художественное тиснение и гравировка (рис. 7/1-5). Эти приемы не получили широкого распростра-
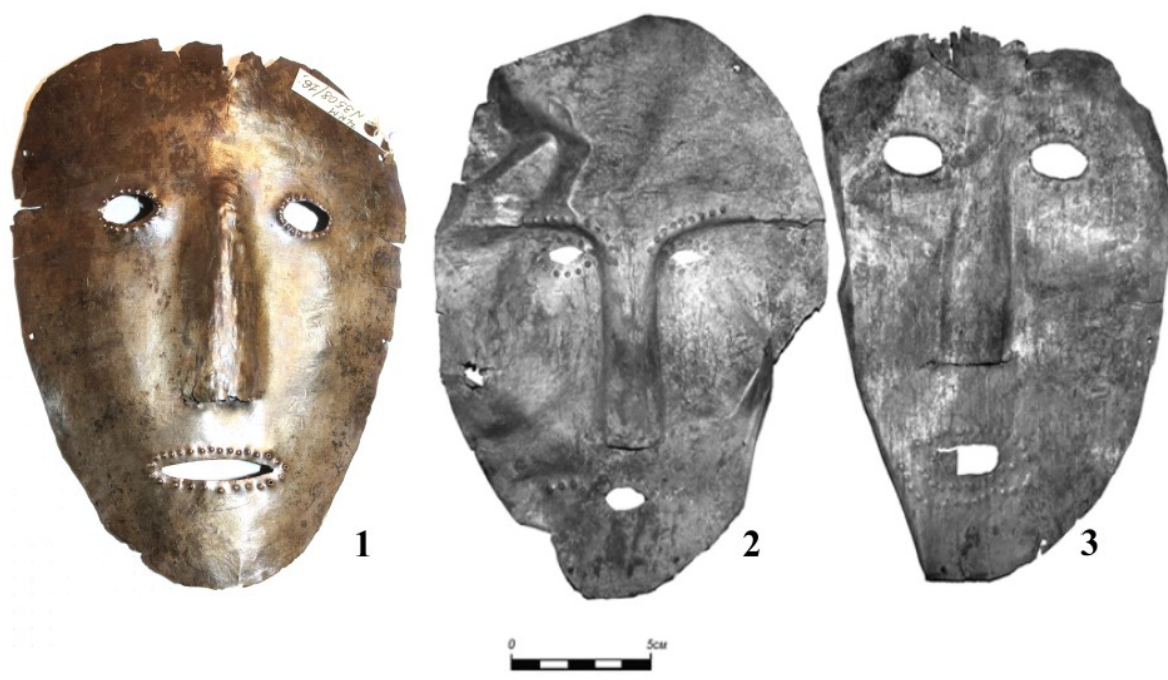

Рис. 6. Примеры прикамских ювелирных изделий с чеканным орнаментом
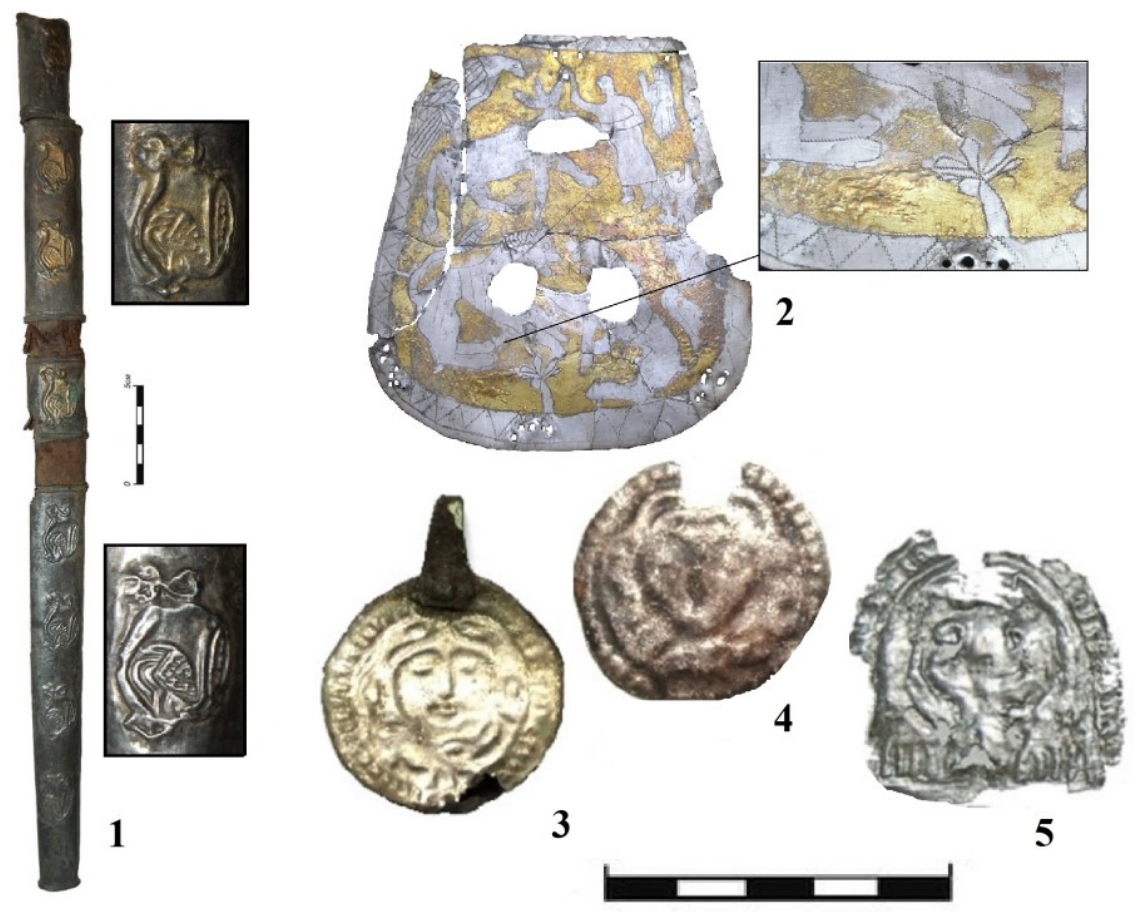

Рис. 7. Примеры прикамских ювелирных изделий с художественным тиснением и гравировкой 
нения среди прикамских ювелиров, и вполне возможно, что известные изделия являются продукцией одного-двух мастеров.

Изделия второй половины $\boldsymbol{X}-\boldsymbol{X I} в \boldsymbol{в .}$ представлены зернофилигранными височными украшениями со сложносоставными булавообразными привесками, разными калачевидными височными украшениями, флаконовидными подвескамиигольниками, арочными шумящими украшениями, медальонами разных форм, украшениями рук (рис. 8).

Для них также характерен зернофилигранный декор и нанесенная на фон изделий позолота. Расширилось декорирование изделий орнаментом, нанесенным с помощью чеканки, и применение каменных, стеклянных и янтарных вставок.

Основные изменения в это время наблюдаются в качестве изготовления декоративных элементов. Зернь в изделиях становится более ровной, подобранной по размеру. Для достижения большего декоративного эффекта преднамеренно использовалось сочетание в одном изделии зерни разного размера (например, чередование треугольников, выложенных из мелкой зерни, и треугольников из зерни среднего диаметра) (рис. 9). С ХІ века в декоре начала дополнительно применяться зернь круп-

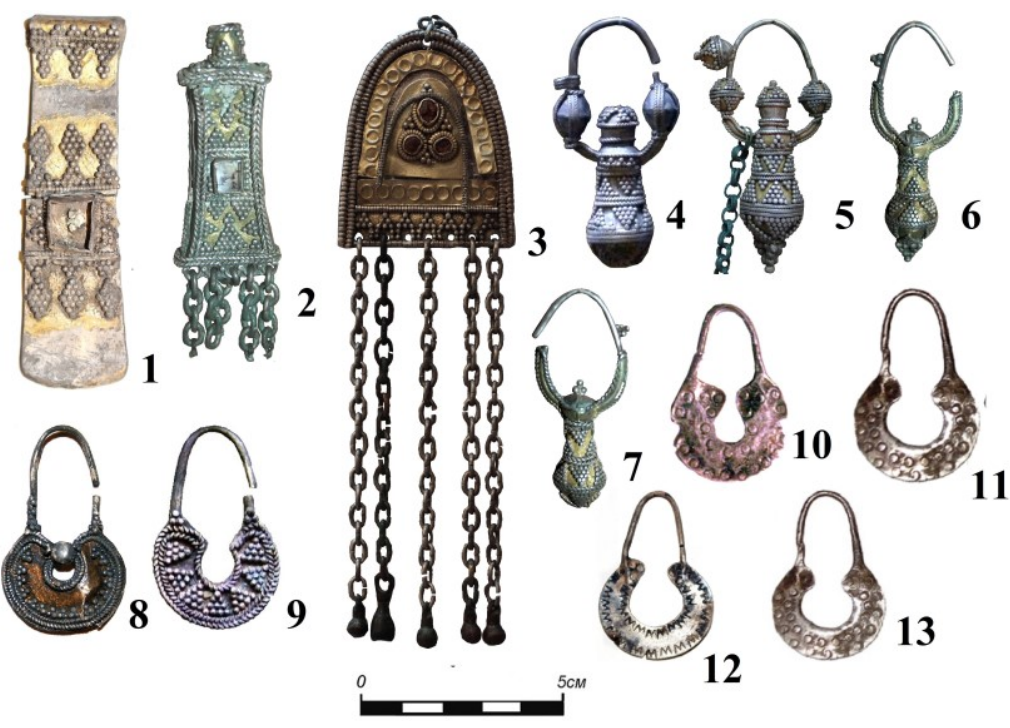

Рис. 8. Прикамские ювелирные изделия второй половины X-XI вв.
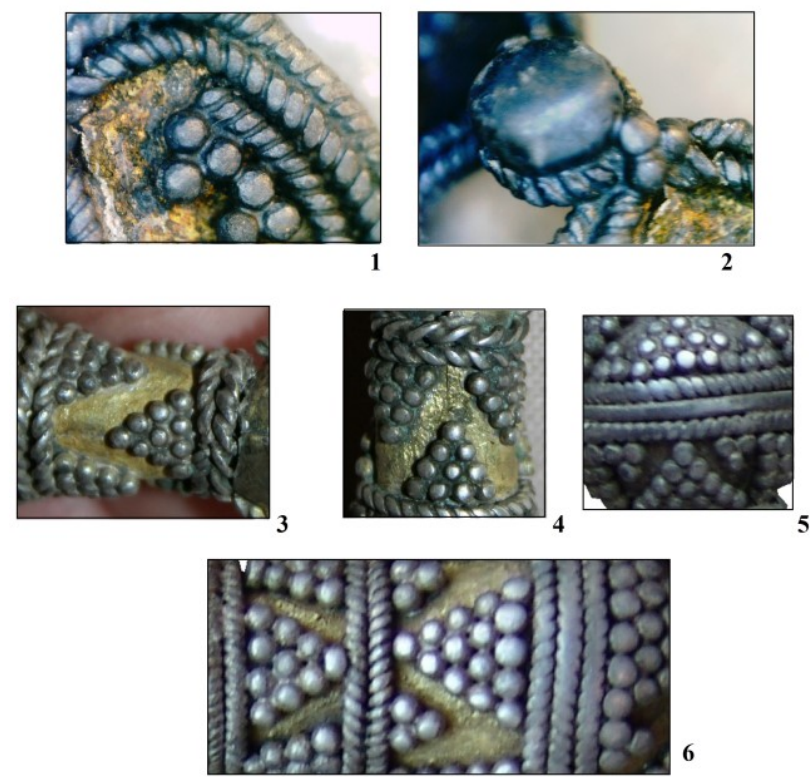

Рис. 9. Зернь и филигрань в изделиях второй половины X-ХІ вв. 
ного размера, выложенная на колечки-подложки из торсированной проволочки, что стало одним из характерных элементов прикамских ювелирных изделий (рис. 9/2).

Филигрань в виде итампованной проволочки стала использоваться гораздо реже, она имеет четкий зерневой эффект (см. рис. 8/3). Преимущество получило использование филиграни в виде торсированной проволочки (проволочки квадратного или прямоугольного сечения, крученой вокруг своей оси и имитирующей скань) (рис. 9/1,3,4). Такие проволочки не только укладывались рядами на местах стыка деталей, но и выступали как отдельный декорирующий элемент. Укладка торсированной проволочки рядами производится так, чтобы соприкасающиеся витки были разнонаправленными относительно друг друга, создавая эффект «косички» (рис. 8/2,4-7,8-9; рис. 9/3,4,6). Также начала использоваться филигрань в виде уплощуенной торсированной проволочки и в виде гладкой уплощуенной проволочки (рис. 9/5,6; преимущественно в XI в.). При этом в одном изделии могла сочетаться филигрань разных видов (рис. 9/5,6).

Во второй половине X - XI вв. отдельные категории ювелирных изделий (например, калачевидные височные украшения) начали широко декорироваться орнаментом, нанесенным с помощью чеканки. В основном чеканкой создавали орнамент из простых геометрических форм в виде кружков, зигзагообразных линий и т.д. (рис. 8/10-13).

Изделия крупных размеров дополнительно декорировались с помощью вставок из разных материалов: янтаря, камня, стекла и отдельных стеклянных или каменных бусин. Вставки представлены разными простыми формами - квадратной и прямоугольной (в виде параллелепипеда), овальной (призматической) и каплевидной, а также в виде простых кабошонов (имеющих одну плоскую поверхность, а другую - выпуклую). Вставка помещалась в специально подготовленный глухой каст, изготовленный из полоски металла, согнутой по форме вставки и припаянной на металлическую основу изделия. Вставка на изделиях крепилась с помощью небольшого заваливания краев каста (края каста только немного накладывались на вставку; рис. 10).
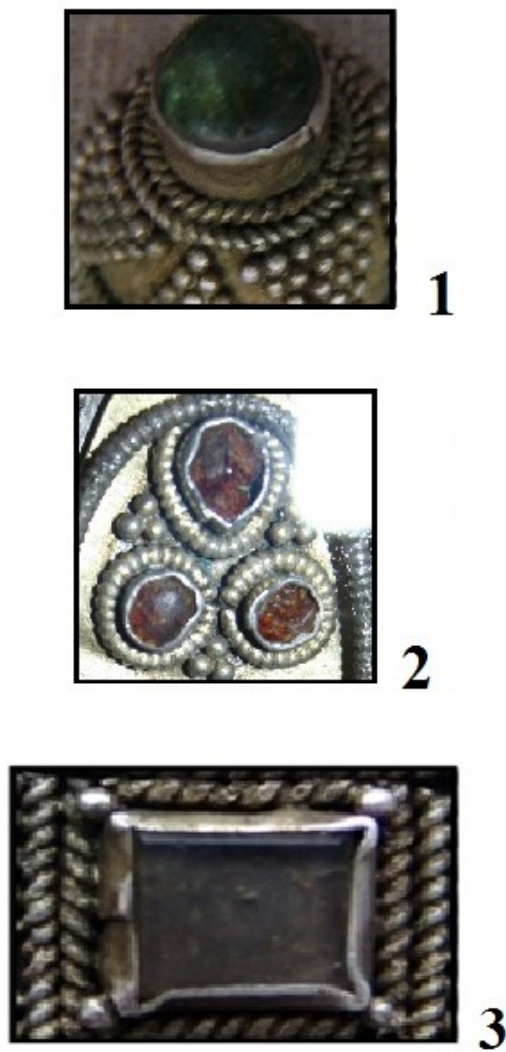

Рис. 10. Инкрустация прикамских ювелирных изделий во второй половине $X-X I$ вв.

Прикамские изделия периода XIIXIII вв. представлены единичными экземплярами зернофилигранных калачевидных височных украшений, бусинными височными украшениями, зернофилигранными медальонами круглой, ромбической и крестовидной форм, зернофилигранными подвесками-лунницами, медальонами с сокольничим, зернофилигранными поясными накладками, пуговицами-бубенчиками, зернофилигранными браслетами со вставками на концах, широкосрединными перстнями с чернью (рис. 11). В XII-XIII вв. декорирование изделий по-прежнему осуществлялось в зернофилигранном стиле с применением фонового золочения.

Зернью выкладываются треугольники и ромбы на поверхности украшений. Так же как и в предыдущий период, зернь 


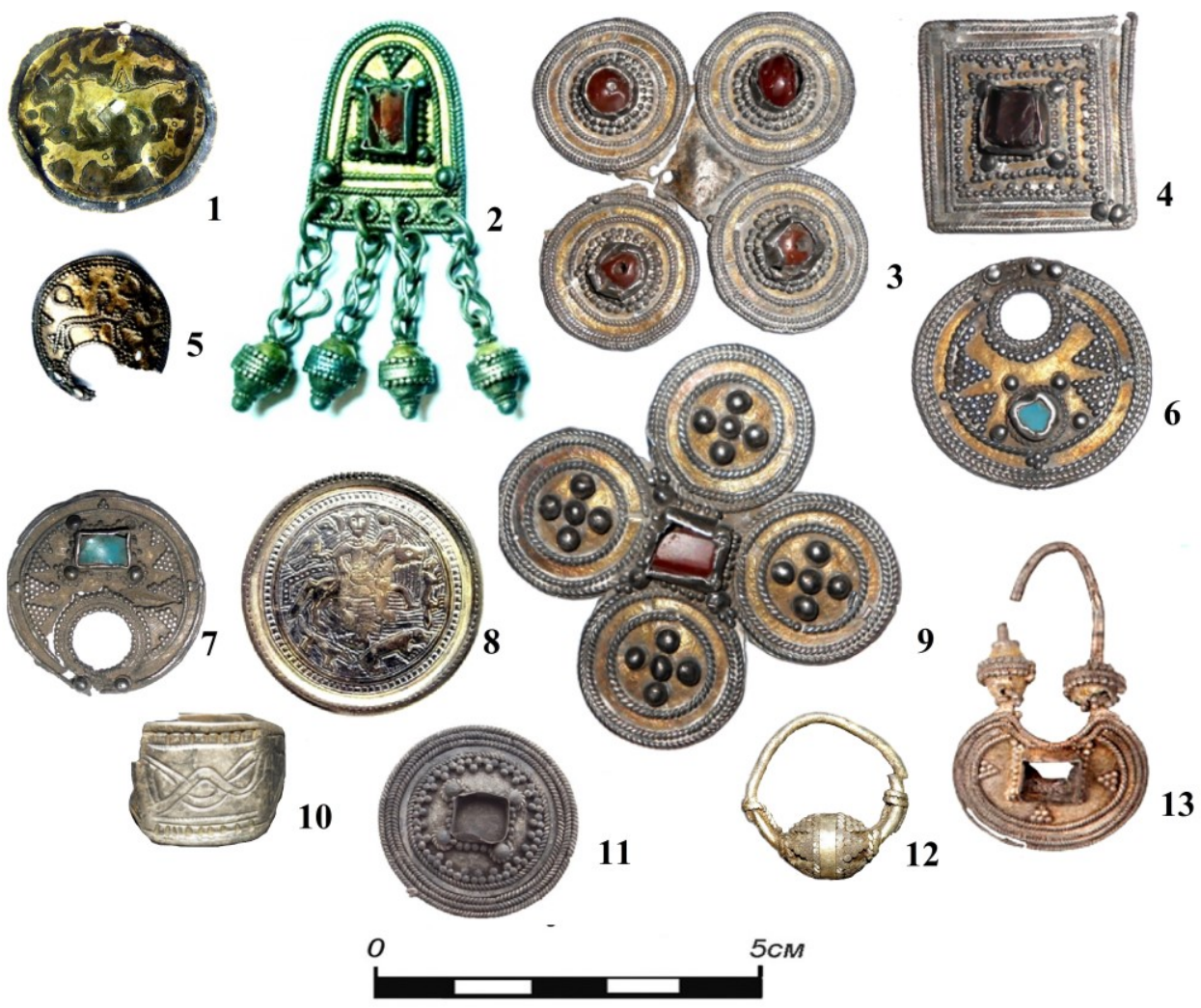

Рис. 11. Прикамские ювелирные изделия XII-XIII вв.

крупного размера укладывалась на подложки, выполненные из торсированной или сканной проволочки (рис. 12).

Филигрань в виде торсированной проволочки в это время стала использоваться реже и постепенно заменяться сканью (филигрань в виде витой проволочки, см. рис. 12), которая, как и торсированная проволока, применялась как в объемном, так и в уплощенном виде. Заново стала широко применяться филигрань в виде штампованной проволочки, имеющая выраженный зерневой эффект.

В XII-XIII вв. между филигранными элементами нередко вместо золочения прокладывается тонкая полоска металла с нанесенной на нее позолотой (рис. 12).
Преимущественно с XIII в. в изготовлении и декорировании ювелирных изделий наблюдается широкое применение контурной чеканки, гравировки и чернения (рис. 11/1,8,10). С помощью контурной чеканки и линейной и зигзагообразной гравировки создавались сложные орнаментальные композиции или изображения. Фон таких изделий, имеющий сложный орнамент, или, наоборот, изображение, заполнялось чернью. Иногда в изделиях с черневым фоном изображения покрывались позолотой (рис. 11/1).

Как и в предыдущий период, некоторые изделия декорируются с помощью вставок из разных материалов: янтаря, камня, стекла и отдельных стеклянных или камен-
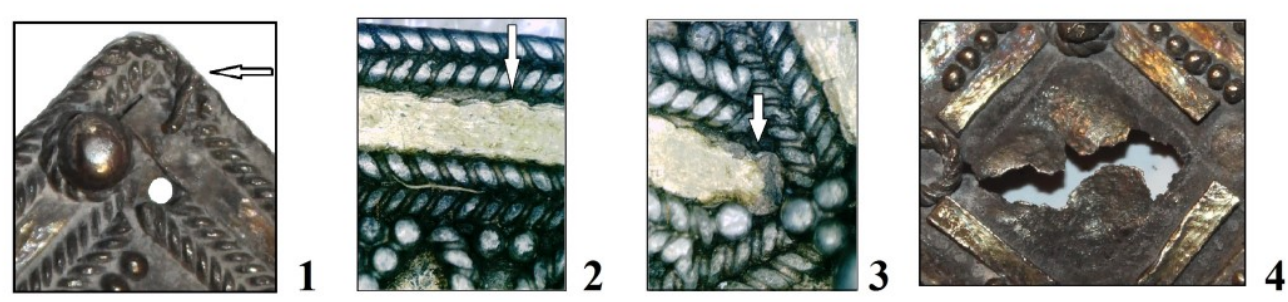

Рис. 12. Особенности зернофилигранного декора в изделиях ХІІ-ХІІІ вв. 
ных бусин. Они также представлены разными простыми формами - квадратной и прямоугольной (в виде параллелепипеда), овальной (призматической) и каплевидной, а также в виде простых кабошонов (имеющих одну плоскую поверхность, а другую - выпуклую). Вставка, так же как и в предыдущий период, помещалась в специально подготовленный глухой касm, изготовленный из полоски металла и припаянный к металлической основе изделия. Однако теперь вставка на изделиях крепится с по- мощью глубокого заваливания краев каста, его края накладывались на вставку с большим припасом и складывались; рис. 13).

Выделенные основные особенности применения ювелирных техник в разные хронологические периоды могут считаться своеобразными маркерами продукции прикамских ювелиров. Они способствуют более точной атрибуции изделий, обнаруженных не только на средневековых памятниках Пермского Предуралья, но и за его пределами.
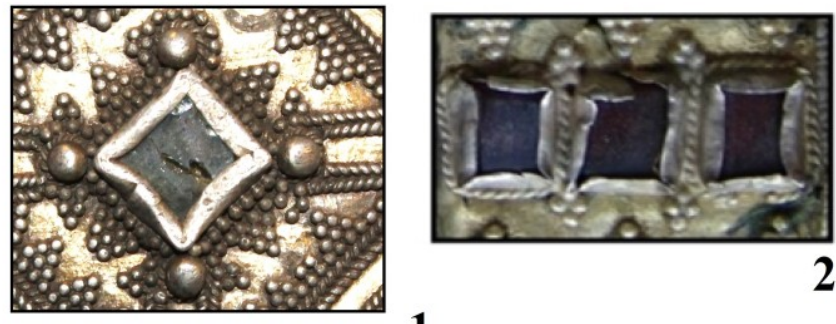

1

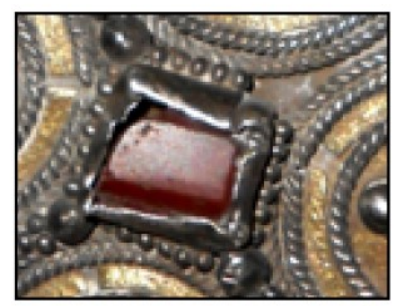

3

Рис. 13. Инкрустащия в прикамских ювелирных изделиях ХІІ-ХІІІ вв.

\section{Библиографический список}

1. Белавин А.М. О своеобразии ювелирной продукции Волжской Болгарии X-XIII вв. // Проблемы финно угорской археологии Урала и Поволжья: сб. материалов конференции. - Сыктывкар: КНЦ УрО РАН, 1992. - С. 142-148.

2. Белавин A.M. Камский торговый путь: средневековое Предуралье в его экономических и этнокультурных связях - Пермь: ПГПУ, 2000. - 200 с.

3. Крыласова Н.Б., Подосёнова Ю.А. Флаконовидные пронизки на территории Пермского Предуралья в эпоху средневековья // Вестник Пермского научного центра УрО РАН. - 2018. - № 2. - С. 49-60.

4. Крыласова Н.Б., Подосёнова Ю.А. Ромбическая ювелирная подвеска из Рождественского городища // Вестник МАЭ ПГГПУ. - 2019. - Вып. 9. - С. 86-93.

5. Макаров Н.A. Русь и Волжская Болгария на Севере // Русь и Восток в IX-XVI вв.: новые археологические исследования. - М.: Наука, 2010. - С. 7-18.

6. Моряхина К.В. Украшения рук средневекового населения Пермского Предуралья / Дис. ...канд. ист. наук: 07.00.06. - Пермь, ПГГПУ, 2019. - 746 с.

7. Подосёнова Ю.А. Калачевидные височные украшения на территории Пермского Предуралья в эпоху средневековья // Вестник МАЭ ПГГПУ. - 2017. - Вып. 7. - С. 38-44.

8. Подосёнова Ю.А. Серебряные пластинчатые подвески с территории Пермского Предуралья эпохи средневековья // Вестник Пермского научного центра. - 2017. - № 4. - С. 100-105.

9. Подосёнова Ю.А. Скано-зерневые трапециевидные подвески с территории Предуралья и Зауралья (родановская, чепецкая, вымская археологические культуры и Приобье) // Человек и север: антропология, археология и экология: материалы Всерос. науч. конф. - Тюмень: ФГБУН ФИЦ ТюмНЦ СО РАН, 2018. - С.187-191.

10. Подосёнова Ю.А. Височные украшения средневекового населения Пермского Предуралья. - Пермь: ПГГПУ-ПФИЦ УрО РАН, 2021. - 210 с.

11. Руденко К.A. Ювелирные изделия Приуралья и Зауралья: к вопросу о булгарском импорте XI-XIV вв. // XVII Уральское археологическое совещание: сб. материалов конференции. - Екатеринбург - Сургут: Магеллан, 2007. - С. 288-289.

12. Руденко К.А. Булгарское серебро. Древности Биляра.- Казань: Заман, 2015. - 528 с.

13. Савельева Э.А., Королев К.С. Торгово-экономические связи Перми Вычегодской с Волжской Булгарией // Известия Коми научного центра УрО РАН. - 2011. - Вып. 3 (37). - С. 89-97. 


\title{
KEY FEATURES OF MEDIEVAL JEWELRY ITEMS OF THE PRE-URALS
}

\author{
Yu.A. Podosenova \\ Perm Federal Research Center UB RAS
}

\section{For citation:}

Podosenova Yu.A. Key features of medieval jewelry items of the Pre-Urals // Perm Federal Research Center Journal. 2021. - № 2. - P. 84-93. https://doi.org/10.7242/2658-705X/2021.2.8

In recent years, due to comprehensive research of jewelry making found at medieval sites in the Perm Pre-Urals, as well as new materials of field archaeological research, convincing evidence has been obtained of the existence of its own jewelry centers here. The items made by medieval masters met the needs of the local population and are represented by costume ornaments, as well as household and ritual items. All of them have a number of distinctive features which are manifested not only in the material and pattern, but also in the methods and techniques of their manufacture and decoration. These features distinguish them among the entire jewelry heritage of the territory of Eurasia in the period of the 9th -13 th centuries.

The paper looks into identifying clear-cut key features (stylistic, chemical and technological) of Prikamye jewellery items. These are certain cultural chronological traditions of the implementation of individual structural elements, the location of the grain-filigree decoration in the manufacture of products and its technical performance, certain methods of inlaying certain categories of jewelry, applying gilding, etc. Fixing these features makes it possible to more accurately attribute the items found both in the medieval monuments of the considered territory and far beyond its borders.

Keywords: Perm Pre-Urals, Middle Ages, jewelry craft, decor, manufacturing, technique, grainfiligree.

\section{Сведения об авторе}

Подосёнова Юлия Александровна, кандидат исторических наук, старший научный сотрудник отдела истории, археологии и этнографии, Пермский федеральный исследовательский центр УрО РАН («ПФИЦ УрО РАН»), 614900, г. Пермь, ул. Ленина, 13А; e-mail: podosenka@yandex.ru 